\title{
Dispersion and dynamics influences from phosphorus deposition on e-coli transport in coastal deltaic lake
}

\begin{abstract}
The study monitor the dynamic pressure from phosphorus deposition on E.coli transport in coastal deltaic lake, such environment were observed to develop lots of negativities from various factors, the study observed high deposition of phosphorus, these substance are micronutrient family that increase the deposition of E.coli in lake and other river environments, the study monitor the behaviour of E.coli in lake under variation of phosphorus pressure in the system, dispersion and dynamic influences from such substances generated fluctuation of E.coli migration in the study environment, the derived solution generated simulation values that were compared with experimental values, and both parameters developed some level of faviourable fits, the study has also observed other environmental factors that may cause fluctuation of the E.coli in the study area.
\end{abstract}

Volume 2 Issue 5 - 2018

\author{
Eluozo $\mathrm{SN},{ }^{\prime}$ Afiibor $\mathrm{BB}^{2}$ \\ 'Department of Civil Engineering, Gregory University Uturu \\ (GUU), Nigeria \\ ${ }^{2}$ Department of Statistics Federal Polytechnic, Nigeria
}

Correspondence: Eluozo SN, Department of Civil Engineering, Gregory University Uturu (GUU) Abia State of Nigeria, Nigeria, Email Soloeluozo2013@hotmail.com

Received: August 3I, 2018 | Published: September 28, 2018

Keywords: dispersion, dynamics, phosphorus, E.coli transport and lakes

\section{Introduction}

The deposition of E-coli in soil and water environment has been a serious concern to environmental health globally, Harvell et al. ${ }^{1}$ express the rate of environmental challenges to have alter serious natural condition thus cause serious negative impact on the environment. The problem has escalated to serious diseases and more pollution around the globe. In the strem rivers and ocean today there serious rise in temperature that has cause increase in proliferation, other part of the world today there increase in cholera due to increase of salt water surface temperature. ${ }^{2}$ Nevertheless, it has been observed by most experts that global warming has some positive impact on human health; for example, Epstein, ${ }^{3}$ even at that bin other part of the world it might chage to negative impact as these climatic condition might reduce snail population including scistosomiasis. More so the spread rise of some other diseases in oceans could be catastrophic to human health on its ambient water bodies and humans. ${ }^{2,4-6}$ Furthermore studies has shown that implementation of an appropriate measures should definitely prevent the transmission of water borne pathogens including death cause this diseases contaminated water. ${ }^{2,7}$ Unsafe rate of pathogens in ambient water bodies has been the major cause of water pollution that has pose serious hazard to public health. Studies from world health organization have explained that over 2.2 billion death and 2.6 billion people lack safe drinking water globally. Deaths annually of 1.4 million are children. ${ }^{8}$ The struggle to ensure that safe drinking water is provided to people could reduce it to about $4 \%$ of the global disease burden. ${ }^{9,10}$ Other related research has also explain these condition in the same state of public health concern, Recent studies such as ${ }^{10-17}$ have evaluation the present state of art and progression in this field, mainly, for freshwater and estuarine sediments. However, gap in the studies has been observed. Besides there are several present evaluation and reviewed precisely on specific water bodies, for instance, John and Rose ${ }^{15}$ focuses on ground water, Brookes ${ }^{11}$ focuses on reservoirs and lakes, and Jamieson et al., ${ }^{12}$ focuses on agriculture watershed. Others, for example, Kay et al., ${ }^{18}$ reviewed on catchment microbial dynamics.

\section{Theoretical background}

$$
\begin{aligned}
& \mathrm{K} \frac{\mathrm{d}^{2} \mathrm{c}}{\mathrm{dx}^{2}}-\varphi \frac{\mathrm{dc}}{\mathrm{dx}}+\mathrm{V}_{\mathrm{t}} \frac{\mathrm{dc}}{\mathrm{dx}}=0 \\
& \mathrm{~K} \frac{\mathrm{d}^{2} \mathrm{c}}{\mathrm{dx}^{2}}-\left(\varphi-\mathrm{V}_{\mathrm{t}}\right) \frac{\mathrm{dc}}{\mathrm{dx}}=0 \\
& \text { Let } \mathrm{C}=\sum_{\mathrm{n}=0}^{\infty} \mathrm{a}_{\mathrm{n}} \mathrm{x}^{\mathrm{n}} \\
& \mathrm{C}^{1}=\sum_{\mathrm{n}=1}^{\infty} \mathrm{na}_{\mathrm{n}} \mathrm{x}^{\mathrm{n}-1} \\
& \mathrm{C}^{11}=\sum_{\mathrm{n}=2}^{\infty} \mathrm{n}(\mathrm{n}-1) \mathrm{a}_{\mathrm{n}} \mathrm{x}^{\mathrm{n}-2} \\
& \mathrm{~K} \sum_{\mathrm{n}=2}^{\infty} \mathrm{n}(\mathrm{n}-1) \mathrm{a}_{\mathrm{n}} \mathrm{x}^{\mathrm{n}-2}-\left(\varphi-\mathrm{V}_{\mathrm{t}}\right) \sum_{\mathrm{n}=1}^{\infty} \mathrm{na}_{\mathrm{n}} \mathrm{x}^{\mathrm{n}-1}=0
\end{aligned}
$$

Replace $n$ in the $1^{\text {st }}$ term by $n+2$ and in the $2^{\text {nd }}$ term by $n+1$, so that we have;

$$
\begin{aligned}
& K \sum_{n=2(4)}^{\infty} n(n+2)(n+1) a_{n+2} x^{n}-\left(\varphi-V_{t}\right) \sum_{n=0}^{\infty}(n+1) a_{n+1} x^{n}=0 \\
& \text { i.e. } K(n+2)(n+1) a_{n+2}=\left(\varphi-V_{t}\right)(n+1) a_{n+1} \\
& a_{n+2}=\frac{\left(\varphi-V_{t}\right)(n+1) a_{n+1}}{K(n+2)(n+1)} \\
& a_{n+2}=\frac{\left(\varphi-V_{t}\right)(n+1) a_{n+1}}{K(n+2)(n+1)}
\end{aligned}
$$


for $\mathrm{n}=0, \mathrm{a}_{2}=\frac{\left(\varphi-\mathrm{V}_{\mathrm{t}}\right) \mathrm{a}_{1}}{2 \mathrm{~K}}$

for $\mathrm{n}=1, \mathrm{a}_{3}=\frac{\left(\varphi-\mathrm{V}_{\mathrm{t}}\right) \mathrm{a}_{2}}{3 \mathrm{~K}}=\frac{\left(\varphi-\mathrm{V}_{\mathrm{t}}\right)^{2} \mathrm{a}_{1}}{2 \mathrm{~K} \bullet 3 \mathrm{~K}}$

for

$\mathrm{n}=2 ; \mathrm{a}_{4}=\frac{\left(\varphi-\mathrm{V}_{\mathrm{t}}\right) \mathrm{a}_{3}}{4 \mathrm{~K}}=\frac{\left(\varphi-\mathrm{V}_{\mathrm{t}}\right)}{4 \mathrm{~K}} \cdot \frac{\left(\varphi-\mathrm{V}_{\mathrm{t}}\right) \mathrm{a}_{1}}{3 \mathrm{~K} \bullet 2 \mathrm{~K}}=\frac{\left(\varphi-\mathrm{V}_{\mathrm{t}}\right)^{3} \mathrm{a}_{1}}{4 \mathrm{~K} \bullet 3 \mathrm{~K} \bullet 2 \mathrm{~K}}$

for $\mathrm{n}=3 ; \mathrm{a}_{5}=\frac{\left(\varphi-\mathrm{V}_{\mathrm{t}}\right)}{5 \mathrm{~K}}=\frac{\left(\varphi-\mathrm{V}_{\mathrm{t}}\right)^{4} \mathrm{a}_{1}}{5 \mathrm{~K} \bullet 4 \mathrm{~K} \bullet 3 \mathrm{~K} \bullet 2 \mathrm{~K}}$

for $\mathrm{n} ; \mathrm{a}_{\mathrm{n}}-\frac{\left(\varphi-\mathrm{V}_{\mathrm{t}}\right)^{\mathrm{n}-1} \mathrm{a}_{1}}{\mathrm{~K}^{\mathrm{n}-1} \mathrm{n} !}$

$C(x)=a_{0}+a_{1} x+a_{2} x^{2}+a_{3} x^{3}+a_{4} x^{4}+a_{5} x^{5}+\ldots \ldots . a_{n} x_{n}$

$=\mathrm{a}_{0}+\mathrm{a}_{1} \mathrm{x}+\frac{\left(\varphi-\mathrm{V}_{\mathrm{t}}\right) \mathrm{a}_{1} \mathrm{x}^{2}}{2 ! \mathrm{K}}+\frac{\left(\varphi-\mathrm{V}_{\mathrm{t}}\right) \mathrm{a}_{1} \mathrm{x}^{3}}{3 ! \mathrm{K}^{2}}+\frac{\left(\varphi-\mathrm{V}_{\mathrm{t}}\right) \mathrm{x}^{4}}{4 ! \mathrm{K}^{3}}+\frac{\left(\varphi-\mathrm{V}_{\mathrm{t}}\right)^{5}}{5 ! \mathrm{K}^{4}}$

$C(x)=a_{0}+a_{1}\left[\frac{\left(\varphi-V_{t}\right) x}{2 ! K}+\frac{\left(\varphi-V_{t}\right)^{2} x^{3}}{3 ! K^{2}}+\frac{\left(\varphi-V_{t}\right)^{3}}{4 ! K^{3}}+\frac{\left(\varphi-V_{t}\right)^{4}}{5 ! K^{4}}\right]$

$\mathrm{C}(\mathrm{x})=\mathrm{a}_{0}+\mathrm{a}_{1} \ell^{\frac{\left(\varphi-\mathrm{V}_{\mathrm{t}}\right)}{\mathrm{K}} \mathrm{x}}$

Subject equation (16) to the following boundary condition

$$
\mathrm{C}(\mathrm{o})=0 \text { and } \mathrm{C}(\mathrm{o})=\mathrm{H}
$$$$
C(x)=a_{0}+a_{1} \ell^{\frac{\left(\varphi-V_{t}\right)}{K} x}
$$$$
\mathrm{C}(\mathrm{o})=\mathrm{a}_{0}+\mathrm{a}_{1}=0
$$$$
\text { i.e. } a_{0}+a_{1}=0
$$

$$
\mathrm{C}^{1}(\mathrm{x})=\frac{\left(\varphi-\mathrm{V}_{\mathrm{t}}\right)}{2 ! \mathrm{K}} \mathrm{a}_{1} \ell^{\frac{\left(\varphi-\mathrm{V}_{\mathrm{t}}\right)}{\mathrm{K}} \mathrm{x}}
$$$$
\mathrm{C}^{1}(\mathrm{o})=\frac{\left(\varphi-\mathrm{V}_{\mathrm{t}}\right)}{2 ! \mathrm{K}} \mathrm{a}_{1}=\mathrm{H}
$$$$
\mathrm{a}_{1}=\frac{\mathrm{HK}}{\varphi-\mathrm{V}_{\mathrm{t}}} \quad \cdots
$$

Substitute (18) into equation (17)

$$
\begin{aligned}
& \mathrm{a}_{1}=\mathrm{a}_{0} \\
& \Rightarrow \mathrm{a}_{0}=\frac{-\mathrm{HK}}{\varphi-\mathrm{V}_{\mathrm{t}}}
\end{aligned}
$$

Hence the particular solution of equation (16) is of the form:

$$
\begin{aligned}
& \mathrm{C}(\mathrm{x})=-\frac{\mathrm{HK}}{\varphi-\mathrm{V}_{\mathrm{t}}}+\frac{\mathrm{HK}}{\varphi-\mathrm{V}_{\mathrm{t}}} \ell^{\frac{\left(\varphi-\mathrm{V}_{\mathrm{t}}\right)}{\mathrm{K}} \mathrm{x}} \\
& \Rightarrow \mathrm{C}(\mathrm{x})=\frac{\mathrm{HK}}{\varphi-\mathrm{V}_{\mathrm{t}}}\left[e^{\frac{\left(\varphi-\mathrm{V}_{\mathrm{t}}\right)}{\mathrm{K}} \mathrm{x}}-1\right] \\
& \mathrm{If} \mathrm{x}=\mathrm{V} \bullet \mathrm{t} \\
& \mathrm{C}(\mathrm{x})=\frac{\mathrm{HK}}{\varphi-\mathrm{V}_{\mathrm{t}}}\left[e^{\frac{\left(\varphi-\mathrm{V}_{\mathrm{t}}\right)}{\mathrm{K}} \mathrm{V} \bullet \mathrm{t}}-1\right] \\
& \mathrm{C}(\mathrm{x})=\frac{\mathrm{HK}}{\varphi-\mathrm{V}_{\mathrm{t}}}\left[\ell^{\frac{\left(\varphi-\mathrm{V}_{\mathrm{t}}\right)}{\mathrm{K}} \frac{\mathrm{d}}{\mathrm{V}}}-1\right]
\end{aligned}
$$

\section{Materials and method}

Standard laboratory experiment where performed to monitor the concentration of E-coli at different positions, the samples were collected in sequences base on the allocated depositions at different locations, this samples collected at different location generated variations at different distance producing different migration of E-coli concentration through introduction of contaminant on the lake, sample were collected at different Distances, the experimental results generated were subject comparison with the theoretical values for model validation.

\section{Result and discussion}

Results and discussion are presented in Tables(1-8) including graphical representation of E-Coli concentration

Table I Predictive and experimental values of e-coli transport at different distance

\begin{tabular}{lll}
\hline Distance $[\mathrm{m}]$ & $\begin{array}{l}\text { Predictive Conc. } \\
{[\mathrm{Mg} / \mathrm{L}]}\end{array}$ & $\begin{array}{l}\text { Experimental } \\
\text { Conc.[Mg/L] }\end{array}$ \\
\hline $\mathrm{I}$ & $2.20 \mathrm{E}-02$ & 0.017 \\
2 & $2.1 \mathrm{IE}-02$ & 0.022 \\
3 & $2.22 \mathrm{E}-02$ & 0.023 \\
4 & $3.35 \mathrm{E}-02$ & 0.026 \\
5 & $3.45 \mathrm{E}-02$ & 0.029 \\
6 & $3.66 \mathrm{E}-02$ & 0.032 \\
7 & $4.23 \mathrm{E}-02$ & 0.035 \\
8 & $4.45 \mathrm{E}-02$ & 0.038 \\
9 & $5.23 \mathrm{E}-02$ & 0.041 \\
10 & $5.44 \mathrm{E}-02$ & 0.044 \\
\hline
\end{tabular}


Table 2 Predictive and experimental values of e-coli transport at different distance

\begin{tabular}{lll}
\hline Distance $[\mathrm{m}]$ & $\begin{array}{l}\text { Predictive Conc. } \\
{[\mathrm{Mg} / \mathrm{L}]}\end{array}$ & $\begin{array}{l}\text { Experimental } \\
{[\mathrm{Mg} / \mathrm{L}]}\end{array}$ \\
\hline $\mathrm{I}$ & $2.12 \mathrm{E}-03$ & 0.002023 \\
2 & $2.17 \mathrm{E}-03$ & 0.002052 \\
3 & $2.22 \mathrm{E}-03$ & 0.002087 \\
4 & $2.25 \mathrm{E}-03$ & 0.002128 \\
5 & $2.28 \mathrm{E}-03$ & 0.002175 \\
6 & $2.32 \mathrm{E}-03$ & 0.002228 \\
7 & $2.38 \mathrm{E}-03$ & 0.002287 \\
8 & $2.52 \mathrm{E}-03$ & 0.002352 \\
9 & $2.54 \mathrm{E}-03$ & 0.002423 \\
10 & $2.60 \mathrm{E}-03$ & 0.0025 \\
\hline
\end{tabular}

Table 3 Predictive and experimental values of e-coli transport at different distance

\begin{tabular}{lll}
$\begin{array}{l}\text { Distance } \\
{[\mathrm{m}]}\end{array}$ & $\begin{array}{l}\text { Predictive Conc. } \\
{[\mathrm{Mg} / \mathrm{L}]}\end{array}$ & $\begin{array}{c}\text { Experimental } \\
{[\mathrm{Mg} / \mathrm{L}]}\end{array}$ \\
\hline $\mathrm{I}$ & $\mathrm{I} .20 \mathrm{E}-0 \mathrm{I}$ & 0.128004 \\
2 & $1.6 \mathrm{IE}-0 \mathrm{I}$ & 0.149032 \\
3 & $1.62 \mathrm{E}-0 \mathrm{I}$ & 0.170108 \\
4 & $1.75 \mathrm{E}-0 \mathrm{I}$ & 0.191256 \\
5 & $1.88 \mathrm{E}-0 \mathrm{I}$ & 0.2125 \\
6 & $1.94 \mathrm{E}-0 \mathrm{I}$ & 0.233864 \\
7 & $2.18 \mathrm{E}-0 \mathrm{I}$ & 0.255372 \\
8 & $2.28 \mathrm{E}-0 \mathrm{I}$ & 0.277048 \\
9 & $2.24 \mathrm{E}-0 \mathrm{I}$ & 0.298916 \\
10 & $2.30 \mathrm{E}-0 \mathrm{I}$ & 0.321 \\
\hline
\end{tabular}

Table 4 Predictive and experimental values of e-coli transport at different distance

\begin{tabular}{lll}
\hline $\begin{array}{l}\text { Distance } \\
{[\mathrm{m}]}\end{array}$ & $\begin{array}{l}\text { Predictive Conc. } \\
{[\mathrm{Mg} / \mathrm{L}]}\end{array}$ & $\begin{array}{c}\text { Experimental } \\
{[\mathrm{Mg} / \mathrm{L}]}\end{array}$ \\
\hline $\mathrm{I}$ & $3.82 \mathrm{E}-04$ & $5.80 \mathrm{E}-05$ \\
2 & $2.7 \mathrm{IE}-04$ & $1.24 \mathrm{E}-04$ \\
3 & $2.72 \mathrm{E}-04$ & $2.46 \mathrm{E}-04$ \\
4 & $2.84 \mathrm{E}-04$ & $4.72 \mathrm{E}-04$ \\
5 & $1.45 \mathrm{E}-03$ & $8.50 \mathrm{E}-04$ \\
6 & $2.84 \mathrm{E}-03$ & $1.43 \mathrm{E}-03$ \\
7 & $1.87 \mathrm{E}-03$ & $2.25 \mathrm{E}-03$ \\
8 & $2.91 \mathrm{E}-03$ & $3.38 \mathrm{E}-03$ \\
9 & $5.94 \mathrm{E}-03$ & $4.84 \mathrm{E}-03$ \\
10 & $6.99 \mathrm{E}-03$ & $6.70 \mathrm{E}-03$ \\
\hline
\end{tabular}

Table 5 Predictive and experimental values of e-coli transport at different distance

\begin{tabular}{lll}
\hline Distance $[\mathrm{m}]$ & $\begin{array}{l}\text { Predictive Conc. } \\
{[\mathrm{Mg} / \mathrm{L}]}\end{array}$ & $\begin{array}{c}\text { Experimental } \\
{[\mathrm{Mg} / \mathrm{L}]}\end{array}$ \\
\hline $\mathrm{I}$ & $2.10 \mathrm{E}-02$ & 0.01793 \\
2 & $2.20 \mathrm{E}-02$ & 0.02172 \\
3 & $2.34 \mathrm{E}-02$ & 0.02537 \\
4 & $3.21 \mathrm{E}-02$ & 0.02888 \\
5 & $3.62 \mathrm{E}-02$ & 0.03225 \\
6 & $3.77 \mathrm{E}-02$ & 0.03548 \\
7 & $3.8 \mathrm{IE}-02$ & 0.03857 \\
8 & $4.82 \mathrm{E}-02$ & 0.04152 \\
9 & $4.85 \mathrm{E}-02$ & 0.04433 \\
10 & $4.88 \mathrm{E}-02$ & 0.047 \\
\hline
\end{tabular}

Table 6 Predictive and experimental values of e-coli transport at different distance

\begin{tabular}{lll}
\hline Distance [m] & $\begin{array}{l}\text { Predictive } \\
\text { Conc. [Mg/L] }\end{array}$ & $\begin{array}{c}\text { Experimental } \\
{[\mathrm{Mg} / \mathrm{L}]}\end{array}$ \\
\hline $\mathrm{I}$ & $2.82 \mathrm{E}-02$ & 0.025009 \\
2 & $2.6 \mathrm{IE}-02$ & 0.025036 \\
3 & $2.62 \mathrm{E}-02$ & $0.02508 \mathrm{I}$ \\
4 & $2.75 \mathrm{E}-02$ & $0.025 \mathrm{I} 44$ \\
5 & $2.88 \mathrm{E}-02$ & 0.025225 \\
6 & $3.44 \mathrm{E}-02$ & 0.025324 \\
7 & $3.68 \mathrm{E}-02$ & $0.02544 \mathrm{I}$ \\
8 & $3.78 \mathrm{E}-02$ & 0.025576 \\
9 & $3.84 \mathrm{E}-02$ & 0.025729 \\
10 & $3.90 \mathrm{E}-02$ & 0.0259 \\
\hline
\end{tabular}

Table 7 Predictive and experimental values of e-coli transport at different distance

\begin{tabular}{lll}
\hline Distance $[\mathrm{m}]$ & $\begin{array}{l}\text { Predictive Conc. } \\
{[\mathrm{Mg} / \mathrm{L}]}\end{array}$ & $\begin{array}{c}\text { Experimental } \\
{[\mathrm{Mg} / \mathrm{L}]}\end{array}$ \\
$\mathrm{I}$ & $2.82 \mathrm{E}-02$ & 0.025009 \\
2 & $2.6 \mathrm{IE}-02$ & 0.025036 \\
3 & $2.62 \mathrm{E}-02$ & $0.02508 \mathrm{I}$ \\
4 & $2.75 \mathrm{E}-02$ & $0.025 \mathrm{I} 44$ \\
5 & $2.88 \mathrm{E}-02$ & 0.025225 \\
6 & $3.44 \mathrm{E}-02$ & 0.025324 \\
7 & $3.68 \mathrm{E}-02$ & $0.02544 \mathrm{I}$ \\
8 & $3.78 \mathrm{E}-02$ & 0.025576 \\
9 & $3.84 \mathrm{E}-02$ & 0.025729 \\
10 & $3.90 \mathrm{E}-02$ & 0.0259 \\
\hline
\end{tabular}


Table 8 Predictive and experimental values of E-Coli transport at different distance

\begin{tabular}{lll}
\hline $\begin{array}{l}\text { Distance } \\
{[\mathrm{m}]}\end{array}$ & $\begin{array}{l}\text { Predictive Conc. } \\
{[\mathrm{Mg} / \mathrm{L}]}\end{array}$ & $\begin{array}{c}\text { Experimental } \\
{[\mathrm{Mg} / \mathrm{L}]}\end{array}$ \\
\hline 1 & $3.20 \mathrm{E}-03$ & 0.00202 \\
2 & $3.4 \mathrm{IE}-03$ & 0.00216 \\
3 & $2.62 \mathrm{E}-03$ & 0.00254 \\
4 & $3.65 \mathrm{E}-03$ & 0.00328 \\
5 & $3.78 \mathrm{E}-03$ & 0.0045 \\
6 & $3.44 \mathrm{E}-03$ & 0.00632 \\
7 & $3.68 \mathrm{E}-03$ & 0.00886 \\
8 & $3.78 \mathrm{E}-03$ & 0.01224 \\
9 & $4.84 \mathrm{E}-03$ & 0.01658 \\
10 & $6.50 \mathrm{E}-03$ & 0.022 \\
\hline
\end{tabular}

The figure has explained the behaviour and dynamic influences on phosphorus deposition in lake, the rate of E.coli transport at various distances were observed and presented in figures, the study express behaviour of the system in terms of various pressure express in different conditions, Figure $1 \& 2$ developed fluctuation in exponential phase to the optimum values recorded at ten metres, but the variation were observed on the predictive values as figure one experienced fluctuation more than Figure 2, while the experimental values observed linear concentration in exponential phase figure three experiences similar condition, the predictive values observe vacillation to the optimum values while the experimental maintained the same trend to the maximum values recorded at the same distances, Figure 4 express graduation increase in concentration to the optimum values recorded at ten metre, while the experimental values maintained the same trend, but with fluctuation on gradual process to the maximum values recorded at the same distances. Figure 5 maintained oscillation base on the pressure from the micronutrient in exponential phase to the optimum values recorded at ten metres, while the experimental parameters in the same trend experiences linear increase but maintained the same exponential phase. Figure 6 observe gradual process of migration and suddenly develop gradual transport between one and five metres, and experiences sudden increase that was observed to the optimum values with gradual increase in concentration. While the experimental values experience linear increase to the maximum values recorded at ten metres. Figure 7 experienced gradual increase in concentration with slight exponential growth in the transport system, while that of the experimental values developed sudden increase to the optimum values at distances of ten metres.

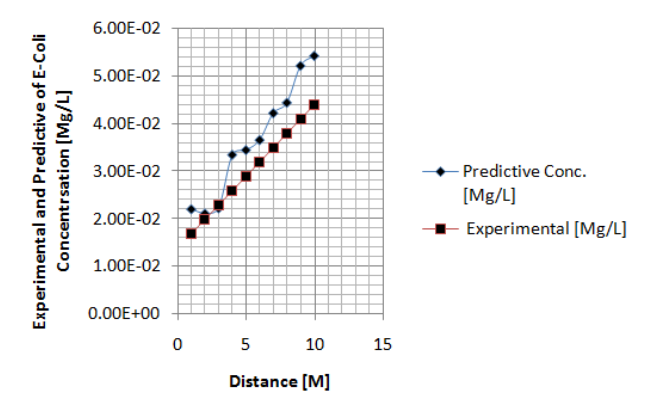

Figure I Predictive and experimental values of e-coli transport at different distance.

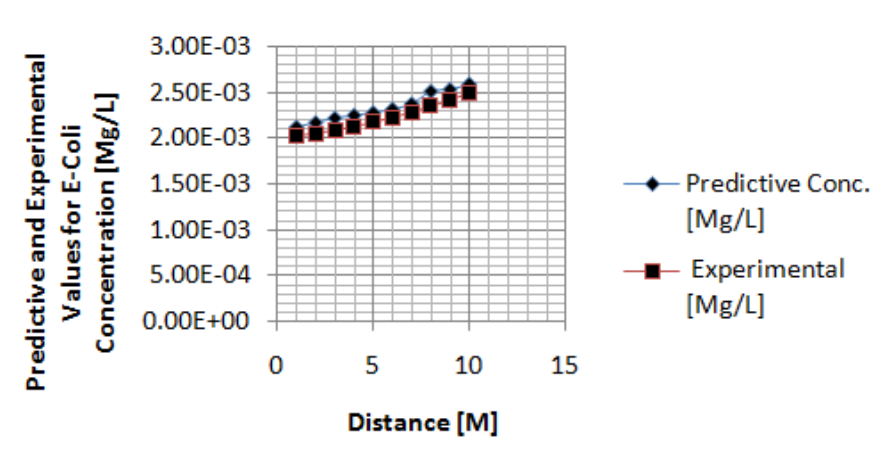

Figure 2 Predictive and experimental values of e-coli transport at different distance.

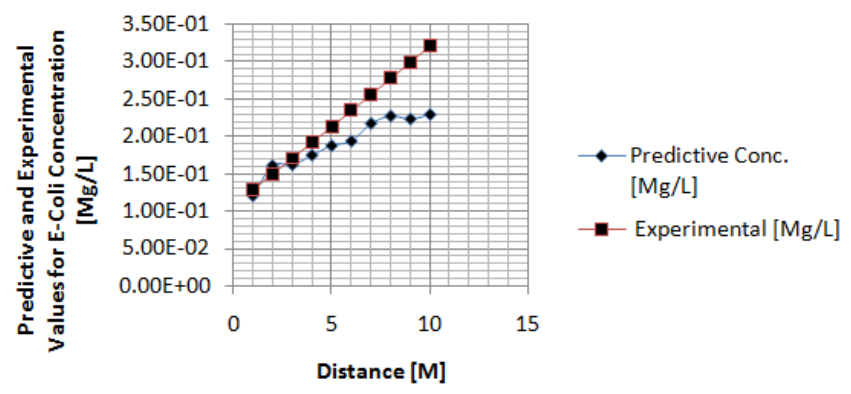

Figure 3 Predictive and experimental values of e-coli transport at different distance.

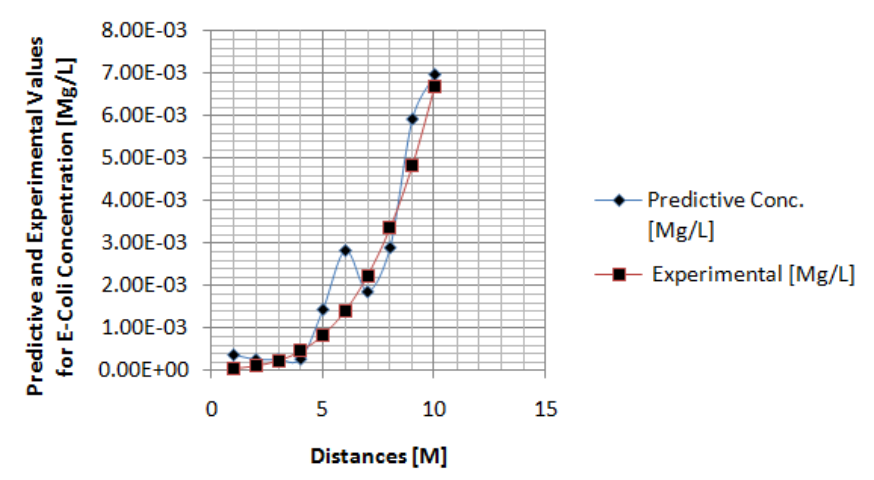

Figure 4 Predictive and experimental values of e-coli transport at different distance.

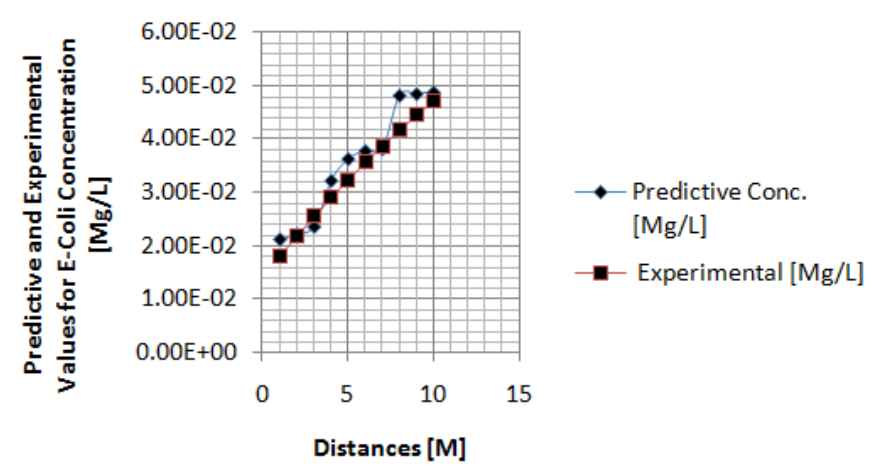

Figure 5 Predictive and experimental values of e-coli transport at different distance. 


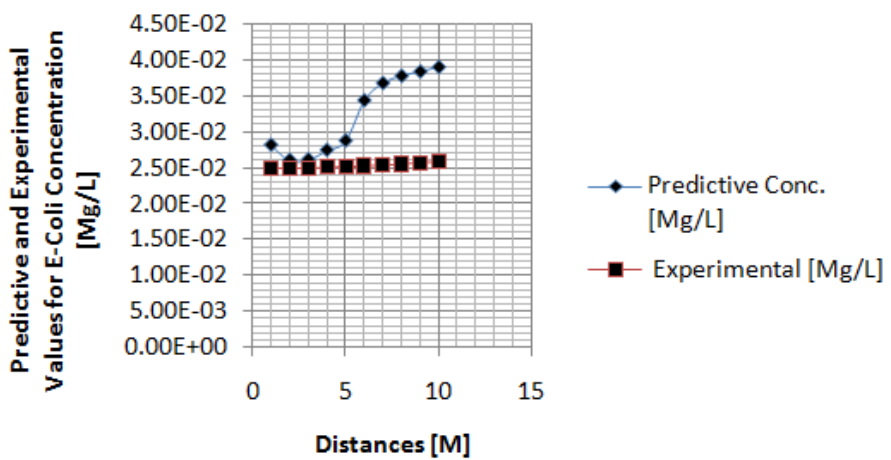

Figure 6 Predictive and experimental values of e-coli transport at different distance.
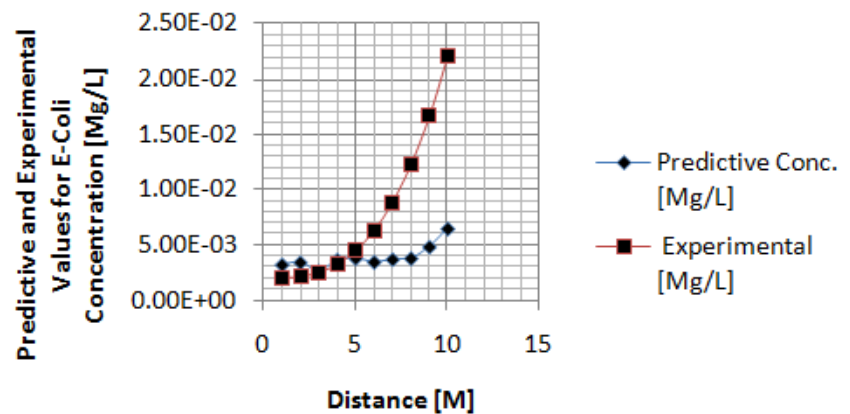

Figure 7 Predictive and experimental values of e-coli transport at different distance.

\section{Conclusion}

The study has monitor the dynamic influences of phosphorus deposition in lakes at coastal deltaic environment, the study has also express the behaviour of E.coli in lake applying these conceptual techniques, the migration process of E.coli in lake experience fluctuation on the predictive parameters, these shows the rate of pressure from phosphorus deposition in the lake, although the velocity of flow experiences degradation in some condition, it definitely implies that the concentration will experiences declined phase as observed in the figure, such condition may not be out of contest, but may be inhibited by other influence in such marine environment, since micronutrients were found in such marine environment, other factors will always cause the inhibition of phosphorus to developed fluctuation effect on the E.coli depositions in lakes thus affect the growth rate. The derived solutions were subjected to simulation, these parameters were compared with experimental values, and both parameter developed favorable fits.

\section{Acknowledgments}

None.

\section{Conflict of interest}

Author declares there is no conflict of interest in publishing the article.

\section{Refernces}

1. Harvell CD, Kim K, Burkholder JM, et al. Emerging Marine Diseases-Climate Links and Anthropogenic Factors. Science. 1999;285(5433):15051510 .

2. Colwell RR. Global climate and infectious disease: The Cholera Paradigm. Science. 1996;274(5295):2025-2031.

3. Epstein PR. Climate change and emerging infectious diseases. Microbes Infect. 2001;3(9):747-754.

4. Martens WJM, Niessen LW, Rotmans J, et al. Potential impact of global climate-change on malaria risk. Environmental Health Perspectives. 1995;103(5):458-464

5. Trenberth KE, Hoar TJ. The 1990-1995 El Nino Southern Oscillation event: Longest on record. Geophysical Research Letters. 1996;23(1):5760 .

6. Harvell CD, Mitchell CE, Ward JR, et al. Climate warming and disease risks for terrestrial and marine biota. Science. 2002;296:2158-2162.

7. Okun DA. From cholera to cancer to cryptosporidiosis. Journal of Environmental Engineering. 1996;122(6):453-458.

8. World Health Organization. Water Sanitation and Health. http://www. who.int/water_sanitation_health/diseases/en/ (accessed on 6/20/2012), 2010 .

9. Pramod KP. Modeling In-Stream Escherichia coli Concentrations A dissertation submitted to the graduate faculty in partial fulfillment of the requirements for the degree of Doctor Of Philosophy Iowa State University Ames, Iowa; 2012.

10. Diffey BL. Solar Ultraviolet-Radiation Effects on Biological-Systems. Physics in Medicine and Biology. 1991;36(3):299-328.

11. Brookes JD, Antenucci J, Hipsey M, et al. Fate and transport of pathogens in lakes and reservoirs. Environ Int. 2004;30(5):741-759.

12. Jamieson R, Gordon R, Joy D, et al. Assessing microbial pollution of rural surface waters: A review of current watershed scale modeling approaches. Agricultural Water Management. 2004;70(1):1-17.

13. Gerba CP, Smith J. Sources of pathogenic microorganisms and their fate during land application of wastes. J Environ Qual. 2005;34:42-48.

14. Gerba CP, McLeod JS. Effect of sediments on the survival of Escherichia coli in marine waters. Appl Environ Microbiol. 1976;32(1):114-120.

15. John DE, Rose JB. Review of factors affecting microbial survival in groundwater. Environment Science \& Technology. 2005;39(19):73457356.

16. Hipsey MR, Antenucci JP, Brookes JD. A generic, process-based model of microbial pollution in aquatic systems. Water Resources Research. 2008;44(7):W07408.

17. Pachepsky YA, Shelton DR. Escherichia coli and fecal coliforms in freshwater and estuarine sediments. Critical Reviews in Environmental Science Technology. 2011;41(12):1067-1110.

18. Kay D, Edwards AC, Ferrier RC, et al. Catchment microbial dynamics: the emergence of a research agenda. Progress in Physical Geography. 2007;31(1):59-76. 